\title{
Mechanical Characteristics and Adhesion of Glass-Kevlar Hybrid Composites by Applying Different Ratios of Epoxy in Lamination
}

\author{
Sajid Hussian Siyal ${ }^{1, *}$, Subhan Ali Jogi ${ }^{1}$, Salman Muhammadi ${ }^{1}$, Zubair Ahmed Laghari ${ }^{1}$, Sadam Ali Khichi ${ }^{1}$, \\ Khalida Naseem ${ }^{2}$, Tahani Saad Algarni ${ }^{3}$, Asma Alothman ${ }^{3}$ (D), Shahid Hussain ${ }^{4, *}$ \\ and Muhammad Sufyan Javed ${ }^{5, *(1)}$
}

\section{check for}

updates

Citation: Hussian Siyal, S.; Ali Jogi, S.; Muhammadi, S.; Ahmed Laghari, Z.; Ali Khichi, S.; Naseem, K.; Saad

Algarni, T.; Alothman, A.; Hussain, S.; Javed, M.S. Mechanical Characteristics and Adhesion of Glass-Kevlar Hybrid Composites by Applying Different Ratios of Epoxy in Lamination. Coatings 2021, 11, 94. https:// doi.org/10.3390/coatings11010094

Received: 27 October 2020 Accepted: 9 January 2021 Published: 15 January 2021

Publisher's Note: MDPI stays neutral with regard to jurisdictional clai$\mathrm{ms}$ in published maps and institutional affiliations.

Copyright: (C) 2021 by the authors. Licensee MDPI, Basel, Switzerland. This article is an open access article distributed under the terms and conditions of the Creative Commons Attribution (CC BY) license (https:// creativecommons.org/licenses/by/ $4.0 /)$.
1 Department of Metallurgy and Materials Engineering, Dawood University of Engineering and Technology-Karachi, Sindh 74800, Pakistan; subhan.duet@gmail.com (S.A.J.); salmanmuhammadi1997@gmail.com (S.M.); zubair.laghari@duet.edu.pk (Z.A.L.); sadam.khichi@hotmail.com (S.A.K.)

2 Department of Chemistry, University of Central Punjab Lahore, Lahore 54000, Pakistan; omeboy007@gmail.com

3 Chemistry Department, College of Science, King Saud University, Riyadh 11451, Saudi Arabia; tahanis@ksu.edu.sa (T.S.A.); zaothman@ksu.edu.sa (A.A.)

4 School of Materials Science and Engineering, Jiangsu University, Zhenjiang 212013, China

5 School of Physical Science and Technology, Lanzhou University, Lanzhou 730000, China

* Correspondence: shahid@ujs.edu.cn (S.H.S.); sajid.hussain@duet.edu.pk (S.H.); safisabri@gmail.com (M.S.J.)

Abstract: Hybrid composites have great potential for specific strength and specific stiffness, effective in aerospace industries, submarines, and light-weight automotives. The mechanical strength and adhesiveness of hybrid laminates can be enhanced by effective use of matrix materials in different ratios of epoxy resin and epoxy hardener. Gentle use of resin and hardener in the fabrication of hybrid composites can alter tensile modulus, the bonding strength between matrix and fabric. Spectacular progress has been achieved by the selection of appropriate amounts of resin and hardener in the hybridization of composite laminate. Hybridization was made by Kevlar inorganic/organic fabrics and glass fabrics stacked with epoxy matrix material. To achieve the combination of mechanical properties and bonding strength, transparent epoxy resin and hardener of commercial grades mixed in various ratios are incorporated as matrix material to fabricate laminate. Three different sheets, named A (3:2), B (4:1), and C (2:3), were embedded by the hand layup method to prepare a hybrid composite. Experimental tests, according to ASTM 3039, were performed to determine the tensile mechanical properties. Peel tests, according to ASTM 6862-11, were performed to investigate the interlaminar strength between Kevlar and glass layers. Shore A and Shore $C$ hardness durometers were used to find out the hardness of the specimens at different spots using the ASTM D-2240 standard. Finally, physical testing, such as density and then water absorption, was carried out using the ASTM D-570 standard to check the swelling ratio of the different specimens. The results obtained highlight that the specimen of the glass/Kevlar hybrid embedded in the ratio 3:2 in lamination has the best mechanical properties (tensile strength and hardness) and the lowest swelling ratio, while the material system in the ratio 4:1 shows the best interlaminar properties and adhesion capabilities.

Keywords: glass/Kevlar; hybrid composites; hand layup; epoxy; hardener; tensile; hardness shore D water absorption; density; peel; ratio

\section{Introduction}

Composites have distinct phases, made by dissimilar fibers and matrix materials. Reinforcement fibers or stacking sheets are employed in matrix materials for making composite structures at the macroscopic level. Matrix materials have a continuous phase and are used as adhesives, and fibers have a discontinuous phase in metal matrix composites (MMCs), ceramic 
matrix composites (CMCs), and polymer matrix composites (PMCs) [1]. Reinforcing synthetic fibers, such as Kevlar fibers, carbon fibers, and glass fibers, and natural fibers, such as jute, sisal, hemp, etc., serve as a dispersed phase in composite materials [2]. In aeronautical applications, light-weight, high-strength organic/inorganic stacked laminated hybrid composites are ideal candidates [3]. The organic fiber Kevlar is five times better than steel due to its specific weight ratio. Kevlar has improved interfacial fracture toughness and degree of symmetry in its internal structure [4]. High-strength aramid fiber is employed as core material in hybrid laminate to prepare light-weight, high-strength bulletproof vests and helmets [5]. In the last few decades, researchers have focused on enhancing the performance of composite materials by mixing synthetic and natural fibers to prepare hybridized structures [6]. E-glass fibers have better ultimate tensile strength and are placed in the outside layer in lamination to produce a flaw-free structure [7]. There is no significant difference in the density if layup placement changes in hybridization [8]. Aramid (Kevlar), a synthetic fiber, was developed in 1965 by two research scientists, Stephanie Kwolek and Herbert Blades. Kevlar belongs to the aromatic polyamide family and consists of extended chains of synthetic polyamide [9]. Aramid fibers have incredible ultimate tensile strength, achieved by intermolecular hydrogen bonds and the aromatic stacking interface of aromatic groups in the neighboring strands [10]. The interatomic bonding is considerably stronger than the van der Waals intermolecular connection in other manmade polymers [11]. Kevlar (aramid) is based on comparatively stiff molecules, which formulate the planar sheet-like arrangement, comparable to silk protein. The intermolecular relation among the molecular strands of Kevlar significantly enhances mechanical strength characteristics and provides superior heat and flame resistivity [12]. Kevlar, which is by now renowned as an elevated-performance fiber, has a remarkable strength-to-weight ratio and improved toughness [13]. As far as cost competitiveness is concerned, glass fiber is cheap and easily available in the market, whereas Kevlar fiber is considerably expensive [14]. To achieve a balance between the cost competitiveness and the strength-to-weight ratio of laminate, hybrid composites are fabricated by stacking E-glass/Kevlar fibers [15]. The amount of water absorption in laminate reduces the mechanical strength of the hybrid composite by weakening the fibers' strength [16,17]. Glass fibers are placed at the interface and Kevlar fibers are used in the core to make a sandwich structure [18]. Glass-fiber-reinforced polymers are used to make printed wire boards for electronic appliances [19]. The mechanical behavior of fiber-reinforced polymers was investigated by understanding ultimate tensile strength, stiffness, and fibermatrix bond strength [20]. Kevlar fibers are used as core in the lamination sequence to suppress the fracture toughness of the hybrid composite [21]. The ratios of epoxy resin to hardener and the volume fraction are effective tools in the fabrication of composite materials [22]. Kevlar fibers reinforced with glass fibers have incredible capacity to produce less dense materials with superior strength, which attain high break and bear resistance characteristics [23]. Epoxy resin and epoxy hardener have good bonding strength and are positioned within layers of fibers to produce rigid and environment-resistant materials [24]. However, the mechanical properties of composite materials strongly depend on the adhesive material as well as the different ratios in which resin and hardener are mixed together to form a matrix phase [25]. The proper use of adhesive materials can supplement the mechanical properties, reduce component weight, increase durability, provide better design latitude, handle high levels of stress, and increase the strength of composites [26]. The performance of the continuous phase is related with the ratio of resin to hardener in the discontinuous phase in hybridization [27]. The interfacial bond strength of the glass/Kevlar hybrid composite is investigated by conducting a peeling test of the hybrid composite laminate [28]. In advanced technologies, materials are required with a combination of properties, such as strength, stiffness, impact, water absorption, and strengthto-weight ratio. Glass/Kevlar hybrid composites have an unusual combination of properties, which cannot be met by other conventional materials [29]. The strength of a composite depends not only on the assets of the matrix but also on how well it sticks to the particles and fibers of the dispersed phase [30]. It is vital that adhesive bonding forces between fiber and matrix be high to minimize fiber pull-out [31]. Sufficient bonding is essential to take advantage of the stress transfer from the weak matrix to the durable fibers. 


\section{Experimental Work}

\subsection{Preparation of Specimens}

In E-glass fabrics with Kevlar 49, each layer has a thickness of $0.5 \mathrm{~mm}$ stacked with epoxy resin and a hardener of commercial grade as adhesive medium for the fabrication of hybrid composites. E-glass fabrics were placed at the top and the bottom, whereas the central layer was of Kevlar 49. In this study, laminates of hybrid composites (A, B, and C) were fabricated (Figure 1) with dissimilar amounts of epoxy resin and hardener using the hand layup method given in Table 1. Materials properties of E-glass, Kevlar, and epoxy given in Table 2.
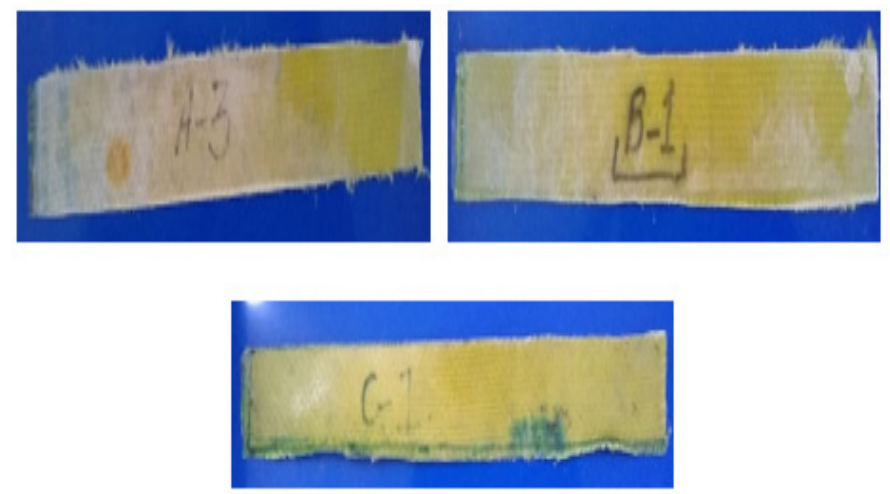

Figure 1. Specimens fabricated using different resin ratios $(A=3: 2, B=4: 1, C=2: 3)$ respectively.

Table 1. Layup placement of glass fibers and Kevlar 49 by applying different ratios of resin and hardener.

\begin{tabular}{cccccc}
\hline $\begin{array}{c}\text { Layer } \\
\text { Formation }\end{array}$ & Layers & Glass Fibers & Kevlar 49 & Ratio of Epoxy Resin & Ratio of Hardener \\
\hline A & 03 & 02 & 01 & 3 & 2 \\
B & 03 & 02 & 01 & 4 & 1 \\
C & 03 & 02 & 01 & 2 & 3 \\
\hline
\end{tabular}

Table 2. Materials properties of E-glass, Kevlar, and epoxy.

\begin{tabular}{ccccc}
\hline Material & $\begin{array}{c}\text { Fiber } \\
\text { Strength }\end{array}$ & $\begin{array}{c}\text { Laminate } \\
\text { Strength }\end{array}$ & $\begin{array}{c}\text { Density of } \\
\text { Laminate (g/cc) }\end{array}$ & $\begin{array}{c}\text { Strength-to- } \\
\text { Weight Ratio }\end{array}$ \\
\hline E-glass & 3450 & 1500 & 2.66 & 564 \\
\hline Kevlar & 2757 & 1430 & 1.44 & 993 \\
\hline Epoxy & N/A & $12-40$ & $1-1.15$ & 28 \\
\hline
\end{tabular}

\subsection{Tensile Test}

During a tension test, standard specimens are placed on the grip of a tensile testing machine (Cometech, Taichung, Taiwan) (Figure 2) so that the specimens undergo tension before fracture. In usual practice, the gauge length of the standard sample increases and the cross-section area reduces during operation. The stress-strain diagram results and the data are analyzed. The standard specimen of ASTM D-3039 was used to conduct the test for a hybrid laminate [32]. Three specimens ( $24 \mathrm{~mm}$ wide and $150 \mathrm{~mm}$ long) were subjected to the grip of a $5 \mathrm{kN}$ universal tensile testing machine. The strain rate $\left(\mathrm{s}^{-1}\right)$ was set to conduct the tensile test for each laminate. The laminate with the same dimensions as those of the glass/Kevlar hybrid with different ratios of epoxy resin and hardener-A (3:2), B (4:1), and $C(2: 3)$ - was examined at room temperature. The results and statistical analysis of specimens $\mathrm{A}, \mathrm{B}$, and $\mathrm{C}$ were tabulated, and the peak stress and peak load of each specimen were investigated considering the stress $\left(\mathrm{N} / \mathrm{mm}^{2}\right)$ and the strain $(\%)$. 


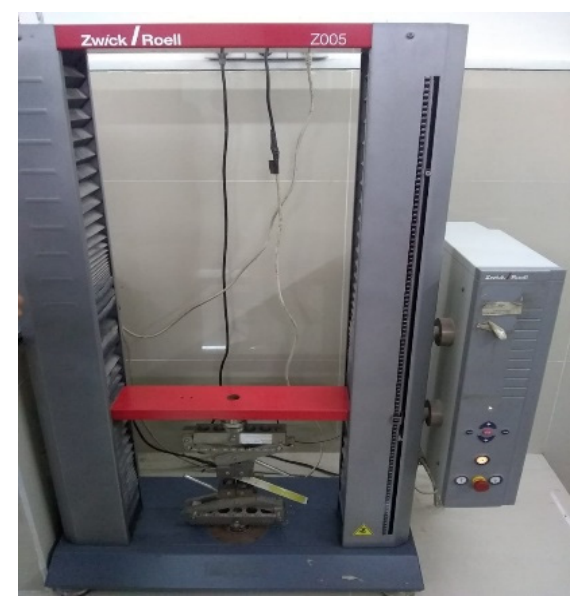

Figure 2. A $5 \mathrm{kN}$ universal tensile testing machine.

\subsection{Peel Test}

The peel adhesion test is used to determine the force required to debond two components joined by a strong adhesive. The test result, also known as bond strength, is generally represented as $N$ (force to debond)/24 mm depending on specimen width. There are various types of peel tests. Examples include the $90^{\circ}$ peel test, $180^{\circ}$ peel test, single lap joint shear test, and T peel test. In this work, $90^{\circ}$ peel tests were performed with two different test setups named type I and type II.

\subsubsection{Sample Preparation}

Three specimens, each being $24 \mathrm{~mm}$ wide and $150 \mathrm{~mm}$ long, was used to perform $90^{\circ}$ peel tests, according to the ASTM D-6862-11 standard [33]. The samples were directly cut from the prepared sheets $(27 \mathrm{~cm} \times 9 \mathrm{~cm})$, in which one of the two glued components was flexible enough to be bent $90^{\circ}$ without breaking.

2.3.2. Type I: When Glass Fiber Is Clamped on Both Upper and Lower Jaws of the UTM for Debonding

One layer of glass fiber is clamped on the upper, movable jaw and another layer of glass fiber is fixed on the lower, fixed jaw of the universal tensile testing machine. The force is set at zero and then, on pushing the start button, the specimen from one end starts debonding, either mechanically or chemically, until the movable layer of glass fiber is completely peeled apart or destroyed.

2.3.3. Type II: When Glass Fiber Is Clamped on the Upper Jaw and Kevlar Is Clamped on the Lower Jaw of the UTM for Debonding

An attempt is made to prevent the glass fiber from breaking during peeling. Kevlar fiber is clamped on the lower, fixed jaw and glass fiber is clamped on the upper, movable jaw to peel apart to check the adhesion between glass fiber and Kevlar by peeling them apart completely.

\section{Hardness Test}

Hardness is resistance to indentation or penetration. Shore A and Shore C durometers are used as portable hardness testers to find the hardness of three specimens. The shore durometer is a device for measuring the hardness of polymers, polymer matrix composites, and elastomers. Higher numbers on the scale indicate a greater resistance to indentation and, thus, harder materials.

The hardness test is carried out as per the ASTM D2240 standard [34] using Shore A and Shore $\mathrm{C}$ durometers shown in Figure 3. An indentation is formed by a given force on a standardized indentation head. This test method is widely used for composite and 
polymer testing. As per ASTM standards, three samples are prepared with different resin and hardener ratios with the dimensions $24 \mathrm{~mm} \times 24 \mathrm{~mm}$.

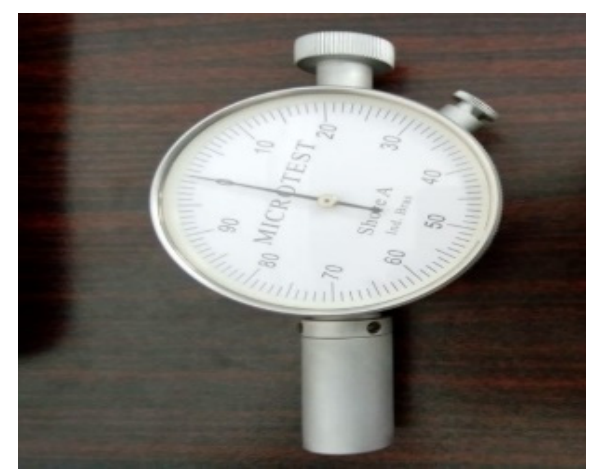

(a)

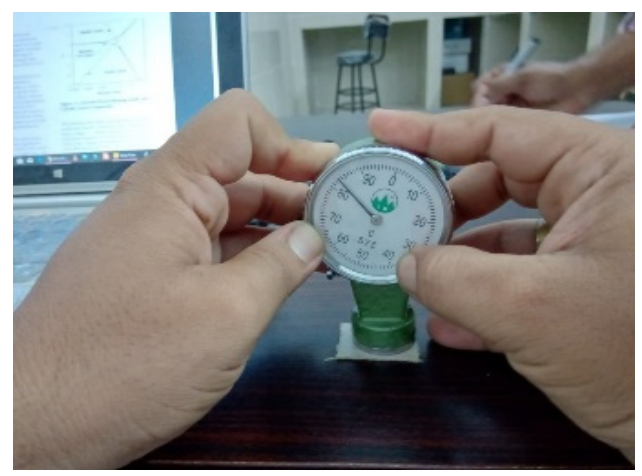

(b)

Figure 3. Shore A (a) and Shore C hardness (b) tester, respectively.

The hardness test was carried out using two types of durometers, Shore A and Shore C. A load was applied, and the readings on the dial were noted down. The indentation was measured from different spots, and mean average values were calculated.

\section{Density Test}

A physical balance was used to evaluate the density of the hybrid composites. As per ASTM standards, three specimens were made. The specimens were placed onto the physical balance and the readings were obtained from the screen. The density was measured by putting the values in the formula Density $=\frac{\text { Mass }}{\text { Volume }}$. The dimensions of the specimen used for the density test were $24 \mathrm{~mm} \times 24 \mathrm{~mm} \times 0.2 \mathrm{~mm}$.

\section{Water Absorption Test}

Water absorption is the amount of water uptake by a material under specific conditions. A physical balance was used to measure the amount of water absorbed by the specimens. As per the ASTM D-570 standard [35], three specimens were fabricated for water absorption, as shown in Figure 4. The samples were first weighed in dry condition and then put into distilled water at $31^{\circ} \mathrm{C}$ for $24 \mathrm{~h}$. The samples were then weighed again.

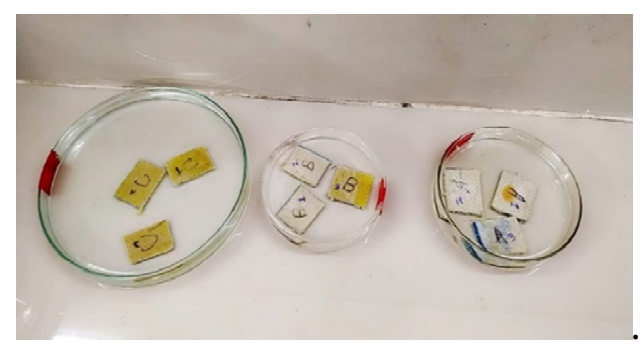

Figure 4. Specimens for the water absorption test using the ASTM D-570 standard.

\section{Measurements}

Water absorption is calculated as an increase in the weight percentage of specimens. Swelling ratio $\%=\frac{\text { Wet laminate area }- \text { Dry laminate area }}{\text { Dry laminate area }} \times 100$ [36] Standard specimens are the same as in the density test $(24 \mathrm{~mm} \times 24 \mathrm{~mm} \times 0.2 \mathrm{~mm})$. 


\section{Results and Discussion}

\subsection{Tensile Test}

A tensile test was carried out using the ASTM standard D-3039 [37] to analyze the mechanical behavior and strength of specimens under tension. The results are shown in the graphs below (Figure 5).
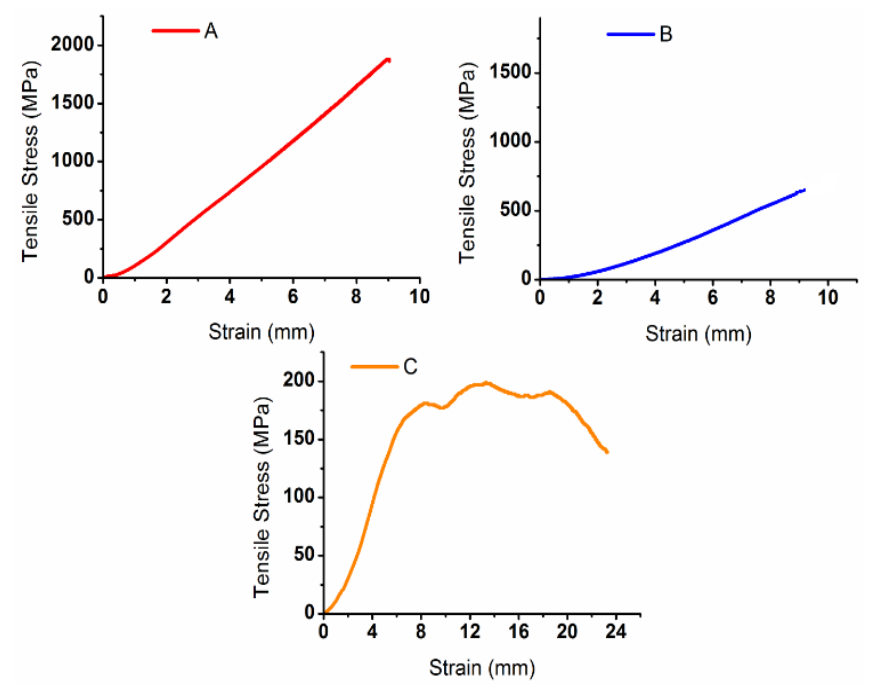

Figure 5. Tensile test results of each configuration: (A-C).

According to the graphs of the tensile test, specimen A, with $60 \%$ resin and $40 \%$ hardener, has the maximum value of stress, $1880 \mathrm{MPa}$, as shown in the graphs in Figure 5. There is a little fluctuation at stress $635 \mathrm{MPa}$ in the graph of specimen B due to the prior breaking of glass fiber than Kevlar. As far as specimen $\mathrm{C}$ is concerned, it has the lowest value of tensile stress due to very poor adhesion between glass fiber and Kevlar with $40 \%$ epoxy resin and $60 \%$ hardener.

\subsection{Peel Test}

As the peel test is performed in two ways, in both conditions, the laminate of same dimensions as those of glass / Kevlar with different ratios of epoxy resin and epoxy hardener (A (3:2), B (4:1), and C (2:3)) was examined at room temperature.

Type I: When Glass Fiber is Clamped on Both Upper and Lower Jaws for Debonding.

Both the upper and lower layers of glass fabric are peeled off from Kevlar fabric, and a graph is plotted against the force required to debond/24 $\mathrm{mm}$ and the strain to examine the adhesiveness between glassy fiber (GF) and Kevlar.

The results of the peel test are shown in Figure 6 in the form of the force required to debond different specimens.

According to this figure, it is clear that specimen B (with $80 \%$ resin and $20 \%$ hardener) uses maximum force in debonding the laminate layers compared to other specimens with codes A and C. This force is expressed as $16.5 \mathrm{~N} / 24 \mathrm{~mm}$. Comparison values of the peel test shown in Figure 7.

Type II: When Glass Fabric is Clamped on the Upper Jaw and Kevlar is Clamped on the Lower Jaw for Debonding.

Kevlar fabric is clamped on the lower, fixed jaw and glass fabric is clamped on the upper, movable jaw to check the adhesion between the glass fabric and Kevlar by peeling them apart completely. Peel test examination of type II shown in Figure 8.

This is a special segment of the peel test, when glass fiber is clamped on the upper jaw and Kevlar is clamped on the lower jaw for debonding, in which an attempt is made to enhance the debonding force. The specimen with code B shows the maximum debonding force (38 N/24 mm) in this case also, as shown in the comparison graph in Figure 9. 


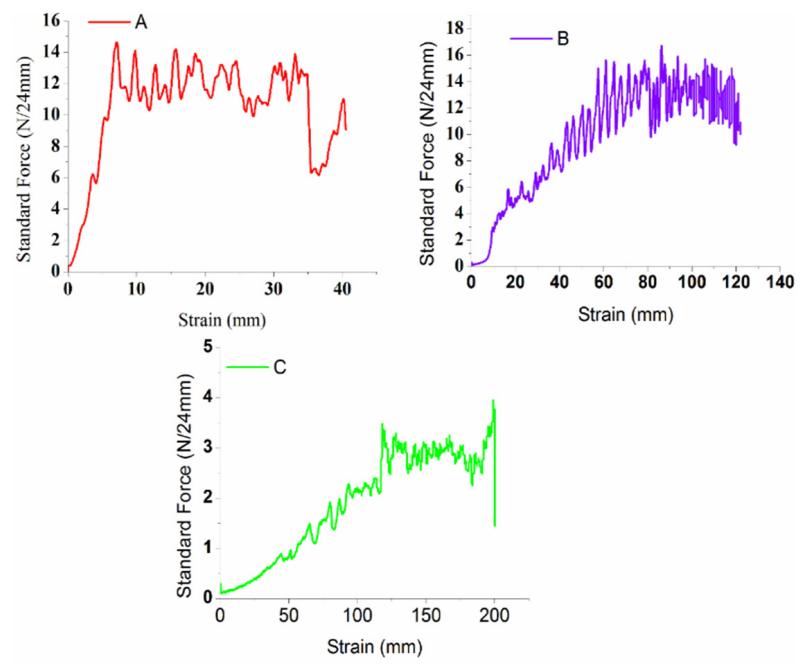

Figure 6. Peel test analysis of type I specimens (A-C).

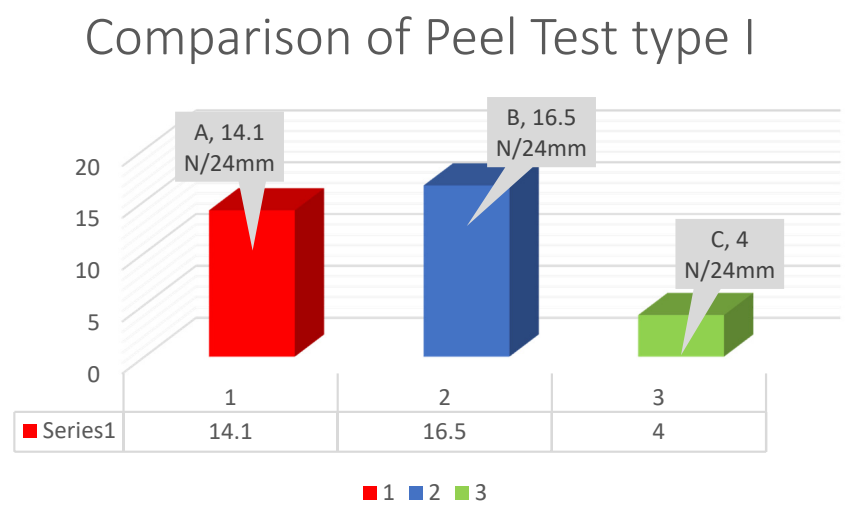

Figure 7. Comparison values of the peel test of type I specimens $(A-C)$.
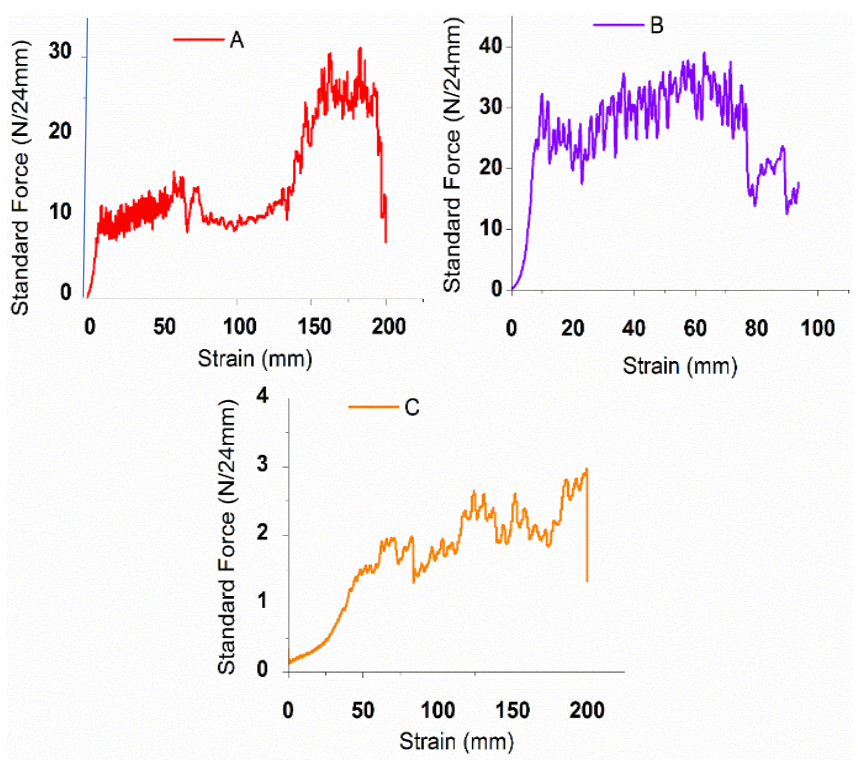

Figure 8. Peel test examination of type II specimens (A-C). 


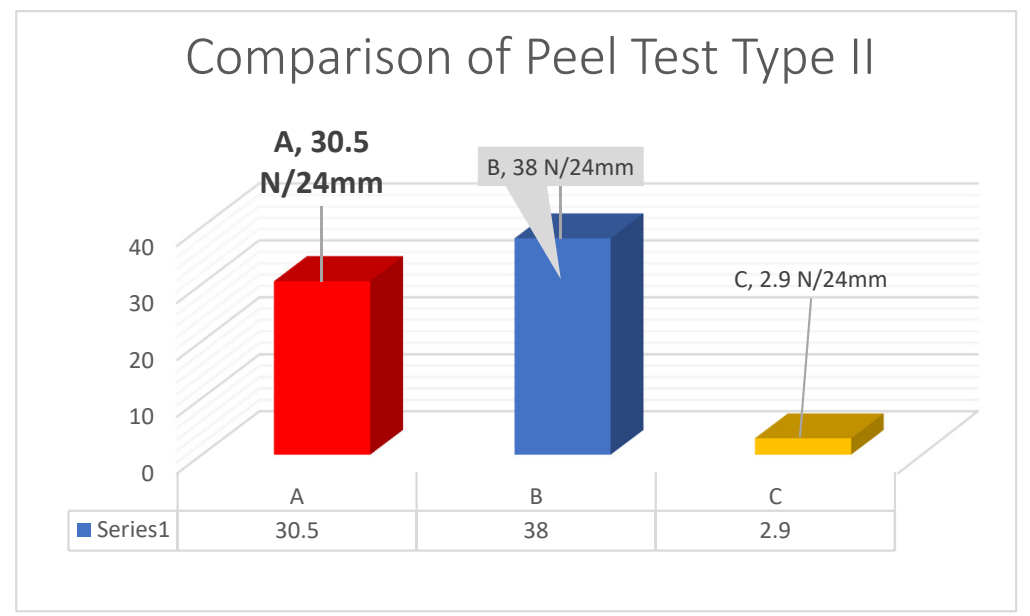

Figure 9. Difference between the peel test results of type II specimens (A-C).

\subsection{Hardness Test}

A portable hardness tester was used to perform the hardness test according to the ASTM A 1038-17 standard [38]. Three samples with size $24 \mathrm{~mm} \times 24 \mathrm{~mm}$ were prepared with different epoxy resin and epoxy hardener ratios $(\mathrm{A}=3: 2, \mathrm{~B}=4: 1$, and $\mathrm{C}=2: 3)$. A load was applied, and the readings on the dial were noted down.

Shore A Hardness Test (Table 3):

Table 3. Shore A hardness of three different specimens.

\begin{tabular}{cccccccccc}
\hline \multirow{2}{*}{ Readings } & \multicolumn{3}{c}{ A } & & & B & & \multicolumn{3}{c}{ C } \\
\cline { 2 - 9 } & A1 & A2 & A3 & B1 & B2 & B3 & C1 & C2 & C3 \\
\hline 1. & 95 & 93 & 96 & 91 & 94 & 94 & 80 & 85 & 80 \\
2. & 96 & 95 & 97 & 93 & 92 & 85 & 85 & 86 & 84 \\
3. & 95 & 91 & 96 & 91 & 95 & 88 & 86 & 84 & 81 \\
Mean of indentation & 95.33 & 93 & 96.33 & 91.66 & 93.67 & 89 & 83.67 & 85 & 81.67 \\
Mean hardness & & 94.887 & & & 91.443 & & & 83.44 \\
\hline
\end{tabular}

Shore C Hardness Test (Table 4):

Table 4. Data analysis of Shore C hardness of three distinct configurations.

\begin{tabular}{|c|c|c|c|c|c|c|c|c|c|}
\hline \multirow{2}{*}{ Readings } & \multicolumn{3}{|c|}{ A } & \multicolumn{3}{|c|}{ B } & \multicolumn{3}{|c|}{$\mathrm{C}$} \\
\hline & A1 & A2 & A3 & B1 & B2 & B3 & $\mathrm{C} 1$ & $\mathrm{C} 2$ & $\mathrm{C} 3$ \\
\hline 1. & 82 & 78 & 85 & 72 & 76 & 75 & 68 & 74 & 65 \\
\hline 2. & 83 & 81 & 86 & 75 & 70 & 78 & 78 & 75 & 68 \\
\hline 3 & 78 & 79 & 86 & 70 & 84 & 77 & 75 & 78 & 66 \\
\hline Mean of indentation & 81 & 79.33 & 85.67 & 72.33 & 76.67 & 76.67 & 73.67 & 75.67 & 66.33 \\
\hline Mean hardness & & 82 & & & 75.23 & & & 71.89 & \\
\hline
\end{tabular}

Tables 3 and 4 report that there is a small variation in harness by applying dissimilar ratios in lamination. It is evident that hardness does not rely on the ratio of matrix material in hybridization [1].

\subsection{Density Test}

According to the results of the density test, specimen A has the best value of density compared to specimens B and C, as described in Table 5. 
Table 5. Measured density of specimens A, B, and C at difference resin ratios.

\begin{tabular}{cccc}
\hline Specimen & Weight $(\mathrm{g})$ & Density $\left(\mathrm{g} / \mathrm{cm}^{\mathbf{3}}\right)$ & Mean $\left(\mathrm{g} / \mathrm{cm}^{3}\right)$ \\
\hline A & 0.98 & 1.0 & 0.96 \\
\hline B & 0.91 & 0.88 & 0.86 \\
\hline C & 0.85 & 0.72 & 0.82 \\
\hline
\end{tabular}

\subsection{Water Absorption Test}

Results of water absorption for specimens A, B, and C by applying different ratios of matrix in lamination given in Table 6.

Table 6. Results of water absorption for specimens A, B, and C by applying different ratios of matrix in lamination.

\begin{tabular}{cccccc}
\hline Specimen & W1 (g) & W2 (g) & $\begin{array}{c}\text { Mean } \\
\text { W1 }\end{array}$ & $\begin{array}{c}\text { Mean } \\
\text { W2 }\end{array}$ & Swelling Ratio \% \\
\hline A & 0.98 & 1.0 & 0.96 & 1.18 & 1.23 \\
\hline B & 0.91 & 0.95 & 0.86 & 1.20 & 1.08 \\
\hline C & 0.85 & 0.78 & 0.82 & 1.32 & 1.46 \\
\hline
\end{tabular}

The water absorption ratio is calculated as an increase in the weight percentage of specimens $\mathrm{A}, \mathrm{B}$, and $\mathrm{C}$ by using the formula Swelling ratio $\%=\frac{\text { Wet laminate }- \text { Dry laminate }}{\text { Dry laminate }} \times 100$. By analyzing Table 5, it is observed that specimen A absorbs the minimal amount of water and, thus, has the minimum swelling ratio compared to specimens $B$ and $C$. From the research findings, it is evident that specimen $A$ has superior strength performance than samples $B$ and C. The minimal swelling ratio is best suited for mechanical properties of hybrid composite materials.

\section{Conclusions}

Efforts were made to enhance the interlaminar adhesion of glass/Kevlar hybrid composites by using dissimilar proportions of epoxy resin and hardener. In this regard, mechanical and physical testing of hybrid composites was performed. Experimental verification shows that the resin and hardener ratio has a profound influence on both the mechanical and physical properties of hybrid composites. The laminate with $60 \%$ resin and $40 \%$ hardener has superior mechanical properties, such as tensile strength hardness and minimum swelling ratio, compared with $40 \%$ resin and $60 \%$ hardener in a matrix, whereas specimens made of $80 \%$ epoxy resin and $20 \%$ hardener have better bonding strength among the layers compared to other specimens. The specimens in which the ratio of hardener is suppressed rather than that of resin have mechanical properties such as adhesion and deduce.

Author Contributions: Conceptualization, S.H.S. and S.A.J.; methodology, S.M. and Z.A.L.; software, S.A.K.; validation, K.N., S.H., and M.S.J.; formal analysis, S.H.; investigation, T.S.A.; resources, T.S.A.; data curation, K.N.; writing—original draft preparation, S.H.S.; writing—review and editing, S.H.; visualization, M.S.J.; supervision, S.H.; project administration, A.A.; funding acquisition, T.S.A. All authors have read and agreed to the published version of the manuscript.

Funding: This work was funded by the Researchers Supporting Project No. (RSP-2020/254) King Saud University, Riyadh, Saudi Arabia.

Data Availability Statement: Data are available in the paper.

Conflicts of Interest: The authors declare no conflict of interest. 


\section{References}

1. Chavali, M.; Palanisamy, P.; Nikolova, M.P.; Wu, R.-J.; Tadiboyina, R.; Rao, P.P. Inorganic composites in biomedical engineering. In Materials for Biomedical Engineering; Elsevier: Amsterdam, The Netherlands, 2019; pp. 47-80.

2. Atiqah, A.; Chandrasekar, M.; Kumar, T.S.M.; Senthilkumar, K.; Ansari, M.N. Characterization and interface of natural and synthetic hybrid composites. Encycl. Renew. Sustain. Mater. 2020, 389-400. [CrossRef]

3. Kashif, M.; Ngaini, Z.; Harry, A.V.; Vekariya, R.L.; Ahmad, A.; Zuo, Z.; Alarifi, A. An experimental and DFT study on novel dyes incorporated with natural dyes on titanium dioxide $\left(\mathrm{TiO}_{2}\right)$ towards solar cell application. Appl. Phys. A 2020, 126, 1-13. [CrossRef]

4. Ahmad, A.; Jini, D.; Aravind, M.; Parvathiraja, C.; Ali, R.; Kiyani, M.Z.; Alothman, A. A novel study on synthesis of egg shell based activated carbon for degradation of methylene blue via photocatalysis. Arab. J. Chem. 2020, 13, 8717-8722. [CrossRef]

5. Zhang, X.Z.; Xu, P.H.; Liu, G.W.; Ahmad, A.; Chen, X.H.; Zhu, Y.L.; Qiao, G.J. Synthesis, characterization and wettability of Cu-Sn alloy on the Si-implanted 6H-SiC. Coatings 2020, 10, 906. [CrossRef]

6. Aravind, M.; Ahmad, A.; Ahmad, I.; Amalanathan, M.; Naseem, K.; Mary, S.M.M.; Zubair, M. Critical green routing synthesis of silver NPs using jasmine flower extract for biological activities and photocatalytical degradation of methylene blue. J. Environ. Chem. Eng. 2020, 9, 104877. [CrossRef]

7. Hussain, S.; Khan, A.J.; Arshad, M.; Javed, M.S.; Ahmad, A.; Shah, S.S.A.; Khan, M.R.; Akram, S.; Zulfiqar; Ali, S.; et al. Charge storage in binder-free 2D-hexagonal $\mathrm{CoMoO}_{4}$ nanosheets as a redox active material for pseudocapacitors. Ceram. Int. 2020. [CrossRef]

8. Saleem, M.; Irfan, M.; Tabassum, S.; Alothman, Z.; Javed, M.S.; Hussain, S.; Zubair, M. Experimental and theoretical study of highly porous lignocellulose assisted metal oxide photoelectrodes for dye-sensitized solar cells. Arab. J. Chem. 2020, 14, 102937. [CrossRef]

9. Naseem, K.; Zia Ur Rehman, M.; Ahmad, A.; Dubal, D.; AlGarni, T.S. Plant extract induced biogenic preparation of silver nanoparticles and their potential as catalyst for degradation of toxic dyes. Coatings 2020, 10, 1235. [CrossRef]

10. Madkour, L.H. Nanoelectronic Materials: Fundamentals and Applications; Springer: Berlin/Heidelberg, Germany, $2019 ;$ Volume 116.

11. Zhan, M.; Hussain, S.; AlGarni, T.S.; Shah, S.; Liu, J.; Zhang, X.; Liu, G. Facet controlled polyhedral ZIF-8 MOF nanostructures for excellent $\mathrm{NO}_{2}$ gas-sensing applications. Mater. Res. Bull. 2021, 136, 111133. [CrossRef]

12. Kashif, M.; Jaafar, E.; Bhadja, P.; Low, F.W.; Sahari, S.K.; Hussain, S.; Al-Tamrah, S.A. Effect of potassium permanganate on morphological, structural and electro-optical properties of graphene oxide thin films. Arab. J. Chem. 2020, 14, 102953. [CrossRef]

13. Tang, L.; Dang, J.; He, M.; Li, J.; Kong, J.; Tang, Y.; Gu, J. Preparation and properties of cyanate-based wave-transparent laminated composites reinforced by dopamine/POSS functionalized Kevlar cloth. Compos. Sci. Technol. 2019, 169, 120-126. [CrossRef]

14. Pandey, J.; Nagarajan, V.; Mohanty, A.K.; Misra, M. Commercial potential and competitiveness of natural fiber composites. In Biocomposites; Elsevier: Amsterdam, The Netherlands, 2015; pp. 1-15.

15. Ahmad, A.; Mubharak, N.M.; Naseem, K.; Tabassum, H.; Rizwan, M.; Najda, A.; Hussain, S. Recent advancement and development of chitin and chitosan-based nanocomposite for drug delivery: Critical approach to clinical research. Arab. J. Chem. 2020, 13, 8935-8964. [CrossRef]

16. Reis, P.N.; Neto, M.A.; Amaro, A.M. Effect of the extreme conditions on the tensile impact strength of GFRP composites. Compos. Struct. 2018, 188, 48-54. [CrossRef]

17. Mustafa, E.H.B.; Dyadyura, K.; Jan, V.; Harničárová, M.; Zajac, J.; Modrák, V.; Pandová, I.; Vrábel, P.; Nováková-Marcinčínová, E.; Pavelek, Z. Manufacturing Technology of Composite Material Structure; Sudan University of Science and Technology: Khartoum, Sudan, 2017.

18. Xiong, J.; Du, Y.; Mousanezhad, D.; Asl, M.E.; Norato, J.; Vaziri, A. Sandwich structures with prismatic and foam cores: A review. Adv. Eng. Mater. 2019, 21, 1800036. [CrossRef]

19. Kwonpongsagoon, S.; Jareemit, S.; Kanchanapiya, P. Environmental impacts of recycled nonmetallic fraction from waste printed circuit board. Int. J. Geomate 2017, 12, 8-14. [CrossRef]

20. Qi, L.; Ju, L.; Zhou, J.; Li, S.; Zhang, T.; Tian, W. Tensile and fatigue behavior of carbon fiber reinforced magnesium composite fabricated by liquid-solid extrusion following vacuum pressure infiltration. J. Alloys Compd. 2017, 721, 55-63. [CrossRef]

21. Pervaiz, M.; Ahmad, I.; Yousaf, M.; Kirn, S.; Munawar, A.; Saeed, Z.; Rashid, A. Synthesis, spectral and antimicrobial studies of amino acid derivative Schiff base metal (Co, Mn, Cu, and Cd) complexes. Spectrochim. Acta Part A Mol. Biomol. Spectrosc. 2019, 206, 642-649. [CrossRef]

22. Rajesh Kumar, G.; Hariharan, V.; Saravanakumar, S.S. Enhancing the free vibration characteristics of epoxy polymers using sustainable phoenix Sp. fibers and nano-clay for machine tool applications. J. Nat. Fibers 2019, 1-8. [CrossRef]

23. Kabir, S.M.F.; Mathur, K.; Seyam, A.M. A critical review on 3D printed continuous fiber-reinforced composites: History, mechanism, materials and properties. Compos. Struct. 2020, 232, 111476. [CrossRef]

24. Anjum, N.; Suresha, B.; Prasad, S.L.A. Influence of Water ageing on mechanical properties of $\mathrm{CaCO}_{3}$ filler filled epoxy resin and sansevieria/carbon fiber reinforced composites. Open J. Compos. Mater. 2019, 9, 1-20. [CrossRef]

25. Liu, M.; Rohde, B.J.; Krishnamoorti, R.; Robertson, M.L.; Dawood, M. Bond behavior of epoxy resin-polydicyclopentadiene phase separated interpenetrating networks for adhering carbon fiber reinforced polymer to steel. Polym. Eng. Sci. 2019, 60, 104-112. [CrossRef] 
26. de Souza, L.C.; Rodrigues, N.S.; Cunha, D.A.; Feitosa, V.P.; Santiago, S.L.; Reis, A.; Loguercio, A.D.; Paris, T.; Saboia, V.d.A.; Perdigao, J. Two-year clinical evaluation of proanthocyanidins added to a two-step etch-and-rinse adhesive. J. Dent. 2019, 81, 7-16. [CrossRef] [PubMed]

27. Braga, R.; Magalhaes, P., Jr. Analysis of the mechanical and thermal properties of jute and glass fiber as reinforcement epoxy hybrid composites. Mater. Sci. Eng. C 2015, 56, 269-273. [CrossRef] [PubMed]

28. Jusoh, M.S.M.; Yahya, M.Y.; Hussein, N.I.S. The effect of fibre layering pattern in resisting bending loads of natural fibre-based hybrid composite materials. In MATEC Web of Conferences; EDP Sciences: Ulis, France, 2016.

29. Xavier, J.; Rodney, K.D.; Prakash, S.J. Mechanical characterisation of epoxy polymer composite reinforced with ramie and synthetic fiber. SSRN Electron. J. 2019. [CrossRef]

30. Kader, W.B. Physico-mechanical properties of typha angustata (elephant grass) fiber reinforced thermoplastic composites. IJAR J. 2019. [CrossRef]

31. Dolan, G.K.; Cartwright, B.; Bonilla, M.R.; Gidley, M.J.; Stokes, J.R.; Yakubov, G. Probing adhesion between nanoscale cellulose fibres using AFM lateral force spectroscopy: The effect of hemicelluloses on hydrogen bonding. Carbohydr. Polym. 2019, 208, 97-107. [CrossRef]

32. Dia, A.; Dieng, L.; Gaillet, L.; Gning, P.B. Damage detection of a hybrid composite laminate aluminum/glass under quasi-static and fatigue loadings by acoustic emission technique. Heliyon 2019, 5, e01414. [CrossRef]

33. Phuong, P.T.M.; Won, H.J.; Oh, Y.J.; Lee, H.S.; Lee, K.D.; Park, S.Y. The chemistry and engineering of mussel-inspired glue matrix for tissue adhesive and hemostatic. J. Ind. Eng. Chem. 2019, 80, 749-756. [CrossRef]

34. Polyzois, G.L.; Tarantili, P.A.; Frangou, M.J.; Andreopoulos, A.G. Physical properties of a silicone prosthetic elastomer stored in simulated skin secretions. J. Prosthet. Dent. 2000, 83, 572-577. [CrossRef]

35. Ab Ghani, M.H.; Ahmad, S. The comparison of water absorption analysis between counterrotating and corotating twin-screw extruders with different antioxidants content in wood plastic composites. Adv. Mater. Sci. Eng. 2011. [CrossRef]

36. Eisenreich, T.J.; Cox, D.S. Modification of the ASTM D 3039 tensile specimen for cryogenic applications. In Materials; Springer: Boston, MA, USA, 1992; pp. 437-444.

37. Jayaraman, T.; Murthy, A.P.; Elakkiya, V.; Chandrasekaran, S.; Nithyadharseni, P.; Khan, Z.; Ashokkumar, M. Recent development on carbon based heterostructures for their applications in energy and environment: A review. J. Ind. Eng. Chem. 2018, 64, 16-59. [CrossRef]

38. Mohsenizadeh, S.; Alipour, R.; Ahmad, Z.; Alias, A. Influence of auxetic foam in quasi-static axial crushing. Int. J. Mater. Res. 2016, 107, 916-924. [CrossRef] 